\title{
Sistem Kelayakan Borang Akreditasi Program Studi Menggunakan Fuzzy Inference System
}

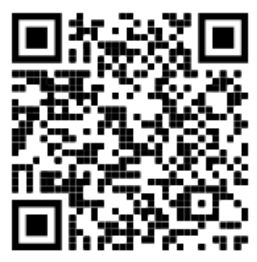

Yanto Hermawan ${ }^{1}$ Irman Hermadi ${ }^{2}$ Heru Sukoco ${ }^{3}$

DOI: https://doi.org/10.36339/jaspt.v4i1.303

1. Mahasiswa Program Studi IImu Komputer, IPB

University Jl. Raya Dramaga Kampus IPB Dramaga Bogor 16680, Indonesia

\section{Abstract}

The Board of National Accreditation for Higher Education evaluates the study program performance. This compels it to improve and maintain its performance. The process of accreditation involves several steps, one of which is the completion of accreditation documents by the study program. The completion requires data from various sources, both from the study program and the institution. However, the data required are often not recorded properly and kept by different sources. As a result, it takes longer time to complete the arrangement. Moreover, inconsistent data format becomes another factor which holds back this process. The application of fuzzy inference system, as used by Kesatuan Business and Informatics Institute, as in the above case can result in a better scoring in which each component is assessed and it will yield the prediction of the expected accreditation status before it is submitted to BAN-PT. This research aims to develop a web based accreditation system with fuzzy inference system and construct a prediction of score ad accreditation status in IBI Kesatuan, using 4 variables of input assessment criteria, namely: external condition, institutional profile, criteria and analysis, and development program decision. The resulting output is the status of nonaccredited, good accredited, excellent accredited, and superior accredited. There are 4 phases in the methods: problem identification, needs and system analysis, system design, system implementation and testing system. The result of blackbox test show that 8 features can operate well. The features consist of criteria menu, indicator menu, date user, LKPS data, LED data, LKPS and LED assessment input, recapitulation and conclusion. Based on the results of the study, it can be concluded that accreditation system can be applied to predict the scores and accreditation status of information system study program of IBI Kesatuan.

Keywords: accreditation, fuzzy inference system

\section{Abstrak}

Badan Akreditasi Nasional Perguruan Tinggi (BAN-PT) menjamin mutu suatu program studi, dimana penilaian kelayakan dan kualitas kinerja program studi perlu dilaksanakan akreditasi. Didalam akreditasi terdapat tahapan penilaian akreditasi yaitu pengisian
2. Dosen Tetap Program Studi IImu Komputer, IPB University JI. Raya Dramaga Kampus IPB Dramaga Bogor

Dosen Tetap Program Stud IImu Komputer, IPB University Jl. Raya Dramaga Kampus IPB Dramaga Bogor 16680, Indonesia

EMail

anto@ibik.ac.id Submitted :
Mei 2020
Accepted :
Juli 2020 JURNAL ANALISIS SISTEM PENDIDIKAN TINGG ISSN $2580-5339$ eISSN $2620-5718$ Volume 4 Nomor 1 JULI 2020 Hal $67-76$

FORUM DOSEN INDONESIA 16680, Indonesia 
dokumen akreditasi oleh pengelola program studi. Pengisian dokumen tersebut membutuhkan data dari berbagai sumber baik dari program studi maupun dari institusi. Akan tetapi, data yang dibutuhkan sering tidak tercatat dengan baik dan berada pada banyak sumber sehingga penyusunan memakan waktu yang lama. Selain itu, format data yang tidak konsisten menjadi faktor lainnya yang menghambat proses pengisian dokumen akreditasi. Penerapan fuzzy inference system dalam kasus diatas dapat menghasilkan perhitungan nilai lebih baik, dimana setiap komponen dinilai dan menghasilkan prediksi status akreditasi yang diharapkan oleh Institut Bisnis dan Informatika Kesatuan (IBI Kesatuan) sebelum diajukan ke BAN-PT. Penelitian ini bertujuan untuk mengembangkan sistem akreditasi berbasis web dengan menggunakan fuzzy inference system dan membuat prediksi nilai dan status akreditasi yang ada di lingkungan IBI Kesatuan, dengan menggunakan 4 variabel kriteria input penilaian yaitu : kondisi eksternal, profil institusi, kriteria dan analisis dan penetapan program pengembangan. Sedangkan output yang akan dihasilkan ialah status tidak terakreditasi, terakreditasi baik, terakreditasi baik sekali dan terakreditasi unggul. Metode yang digunakan terdiri dari 4 fase yaitu identifikasi masalah, analisa kebutuhan dan sistem, perancangan sistem, implementasi sistem serta pengujian sistem, hasil test blackbox menunjukan bahwa 8 fitur sistem bisa berjalan dengan baik. Fitur-fiturnya terdiri dari menu kriteria, menu indikator, data user, data LKPS, data LED, input penilaian LKPS dan LED, rekapitulasi dan kesimpulan. Berdasarkan hasil studi, dapat disimpulkan bahwa sistem akreditasi dapat diterapkan untuk memprediksi nilai dan status akreditasi pada program studi sistem informasi di IBI Kesatuan.

Kata kunci: akreditasi, fuzzy inference system

Kata Kunci: akreditasi, sistem inferensia fuzzy

\section{PENDAHULUAN}

Akreditasi program studi saat ini dilakukan oleh Badan Akreditasi Nasional Perguruan Tinggi (BAN-PT). BAN-PT ditunjuk mewakili pemerintah untuk menjamin mutu pada suatu institusi Perguruan Tinggi dan program studi dan BAN-PT menggunakan Instrumen Akreditasi Program Studi (IAPS) untuk mengukur kelayakan dan kualitas kinerja dari suatu program studi, kemudian hasil akreditasi digunakan sebagai penilaian kelayakan dan kualitas kinerja program studi dalam melaksanakan sistem pendidikannya. Pada tahap penilaian akreditasi terdapat pengisian dokumen akreditasi oleh pengelola program studi. Pengisian dokumen tersebut membutuhkan data dari berbagai sumber baik dari program studi maupun dari institusi. Data yang dibutuhkan sering tidak tercatat dengan baik dan berada pada banyak sumber sehingga penyusunan memakan waktu yang lama. Selain itu, format data yang tidak konsisten menjadi faktor lainnya yang menghambat proses pengisian dokumen akreditasi. Selain BAN-PT yang melakukan dalam hal pemeringkatan terdapat institusi atau organisasi yang menyelenggarakan pemeringkatan diantaranya Webometrics, QS World University, Times Higher Education World University.

JAS-PT

JURNAL ANALISIS SISTEM PENDIDIKAN TINGGI ISSN $2580-5339$ eISSN $2620-5718$

Volume 4

Nomor 1

JULI 2020

Hal $67-76$

FORUM DOSEN INDONESIA
Saat ini di Institut Bisnis dan Informatika Kesatuan (IBIK) dalam penyusunan IAPS dibutuhkan data terdiri dari data visi misi, kerjasama, mahasiswa, sumber daya manusia, keuangan, sarana dan prasarana, pendidikan, penelitian, pengabdian kepada masyarakat dan luaran capaian tridharma data ini diperlukan dalam penyusunan IAPS, dalam penyusunan IAPS dibagi menjadi 2 yaitu laporan kinerja program studi (LKPS) dan laporan evaluasi diri (LED). Saat ini terdapat kendala dalam pengumpulan berkas di masing-masing unit antara lain sumber data mahasiswa dan lulusan belum terpusat, 
kemudian laporan sumber dana dan alokasi dana dikarenakan perbedaan format laporan keuangan yang diminta BAN-PT serta, tidak terdokumentasinya kegiatan yang telah dilakukan, kemudian dalam melakukan perhitungan IBIK kesulitan dalam menentukan prediksi nilai sementara sebelum diajukan ke BAN-PT, dikarenakan belum adanya suatu sistem yang terintegrasi saat ini. Masalah di atas dapat diselesaikan oleh implementasi sebuah sistem akreditasi.

Penelitian Maulana (2014) telah mengembangkan aplikasi Sistem Informasi Akreditasi Program Studi (SIAPS) dengan modul keuangan, dari penelitian tersebut menghasilkan modul keuangan sebagai salah satu bagian pada SIAPS yang dapat mengelola berbagai macam sumber data menjadi tabel-tabel dokumen akreditasi sesuai dengan standar akreditasi BAN-PT, agar pengelola program studi dapat mengisi dokumen akreditasi dengan cepat dan efisien. Penelitian Hamidah (2018) telah mengembangkan Sistem Informasi Akreditasi Berbasis Web Untuk Modul Keuangan, Sarana, Prasarana dan Sistem Pembelajaran pada Program Sarjana Penelitian ini bertujuan menghasilkan modul keuangan, sarana, prasarana, dan sistem pembelajaran sebagai bagian dari SIMAPROSA untuk memudahkan program studi dalam mengelola, mengolah, dan mengumpulkan data dalam bentuk borang 3A. Selain itu, sistem ini diharapkan dapat memudahkan FMIPA dalam melakukan perekapan laporan ke dalam borang 3B.

Berdasarkan paparan sebelumnya, pada penelitian ini akan dikembangkan Sistem Akreditasi Program Studi (SIAPRO) aplikasi SIAPRO. SIAPRO akan dibuat dengan penilaian di masing-masing kriteria dengan menggunakan IAPS 9 kriteria, yang telah ditentukan BAN-PT.

\section{METODE PENELITIAN}

Akreditasi program studi saat ini dilakukan oleh Badan Akreditasi Nasional Perguruan Tinggi (BAN-PT). BAN-PT ditunjuk mewakili pemerintah untuk menjamin mutu pada suatu institusi Perguruan Tinggi dan program studi dan BAN-PT menggunakan Instrumen Akreditasi Program Studi (IAPS) untuk mengukur kelayakan dan kualitas kinerja dari suatu program studi.

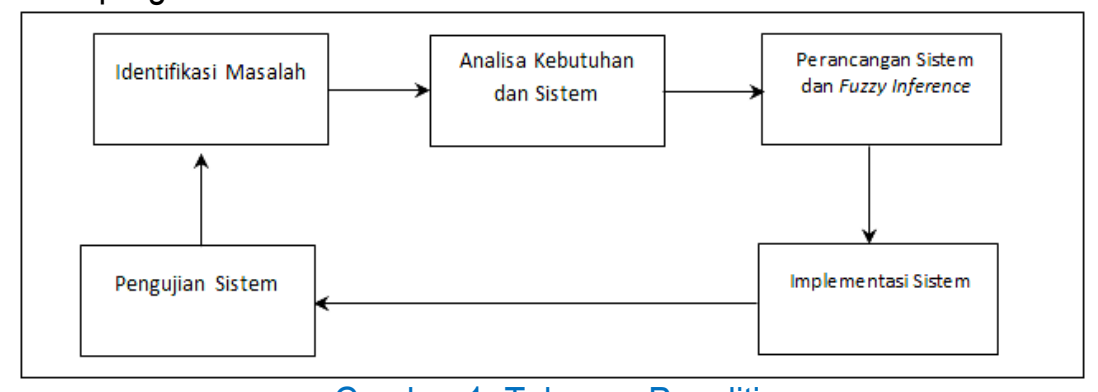

Gambar 1. Tahapan Penelitian

\section{Identifikasi Masalah}

Pada tahap penelitian ini mengidentifikasi permasalahan yang terjadi pada pengolahan data akreditasi dan membuat nilai untuk masing-masing standar, dengan cara membaca liteuratur dan permasalahan utama dari pengolahan data akreditasi sebagai acuan untuk perancangan sistem akreditasi.

\section{Analisa Kebutuhan dan sistem}

Tahap berikutnya ialah analisa kebutuhan untuk merumuskan fitur-fitur yang akan dikembangkan dalam sistem. Adapun fitur utama yang akan dikembangkan adalah menu indikator, menu LKPS, menu LED, menu penilaian dan menu rekapitulasi. Analisa

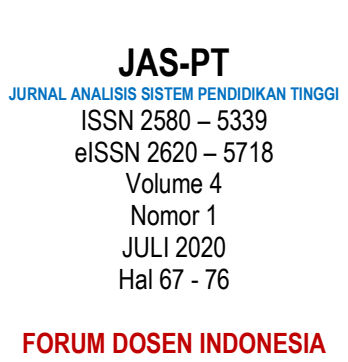


kebutuhan lainnya adalah sistem inferensi fuzzy solusi yang dapat dilakukan adalah dengan logika fuzzy, yang merupakan sistem inferensi fuzzy menggunakan metode Mamdani. Jenis Mamdani, nilai setiap parameter akan dihitung dalam nilai setiap kelompok nilai di setiap parameter. Perhitungan derajat untuk setiap parameter dilakukan menggunakan rumus trapesium. Nilai keanggotaan yang diperoleh akan menjadi input dalam proses mengevaluasi aturan berdasarkan pengetahuan.

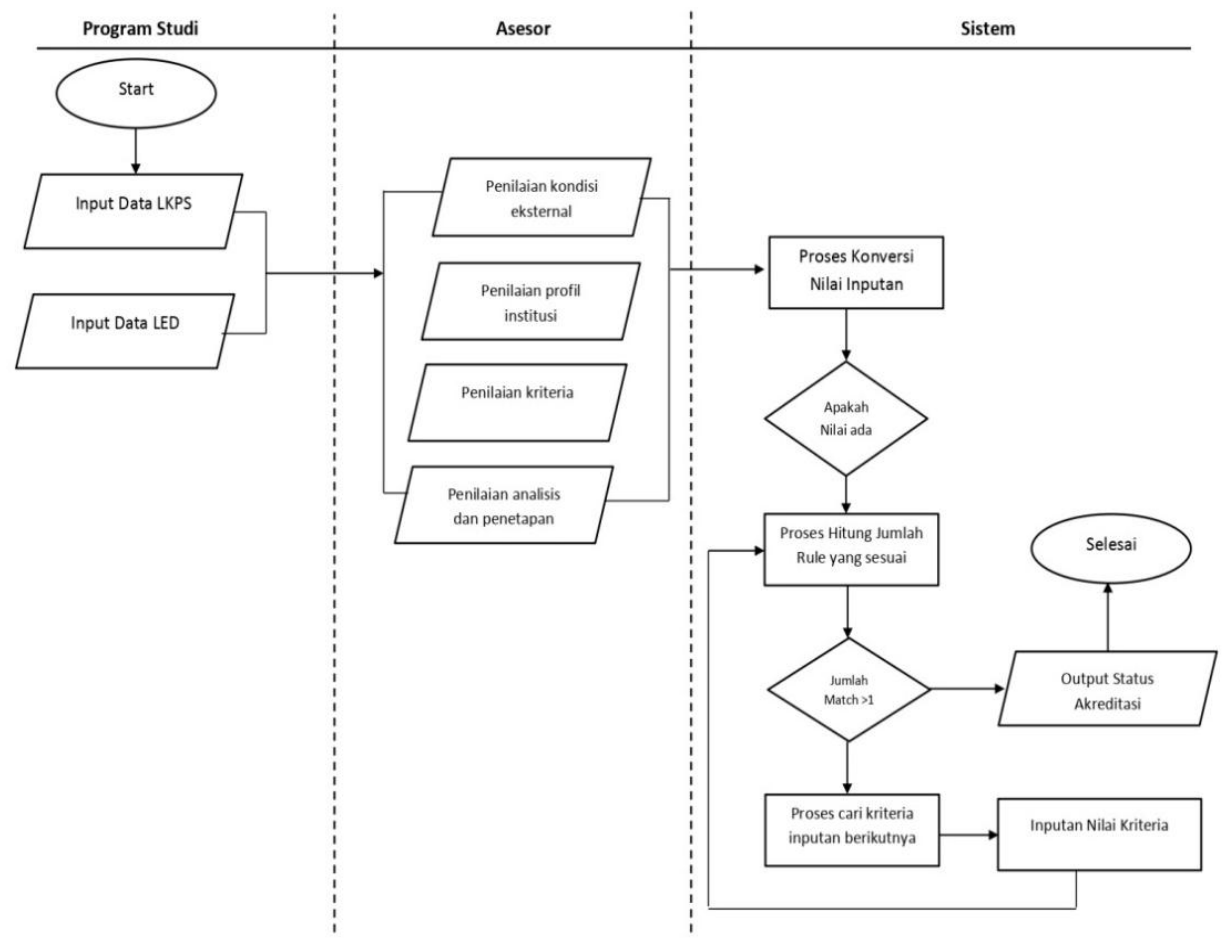

Gambar 2 Flowchart penilaian akreditasi

\section{Perancangan Sistem}

Pada tahap ini perancangan sistem bertujuan menggambarkan sistem secara konseptual. Adapun perangkat yang dibutuhkan dalam perancangan berbasis objek adalah menggunakan pendekatan model UML (Unified Modeling Language) yaitu perancangan use case diagram.

Implementasi Sistem

Implementasi dilakukan dengan menggunakan bahasa pemrograman (PHP) dengan menerapkan framework Codelgniter. Pembuatan basis data dilakukan menggunakan DBMS Mysql.

\section{HASIL DAN PEMBAHASAN}

\section{Hasil Perancangan Sistem}

JAS-PT

JURNAL ANALISIS SISTEM PENDIDIKAN TINGGI

ISSN $2580-5339$

eISSN $2620-5718$

Volume 4

Nomor 1

JULI 2020

Hal 67 - 76

Tahap perancangan ini adalah melakukan pembuatan use case, use case description dan activity diagram berdasarkan analisis kebutuhan sebelumnya. Use case ini menujukan task yang dapat dilakukan oleh pengguna, seperti menambahkan data, menghapus data, dan mengubah data. Berikut akan dibahas mengenai Use case Admin memasukan data data master mengenai data indikator, data penilaian serta data user. Data yang diisikan oleh admin akan di isi data data oleh program studi. 


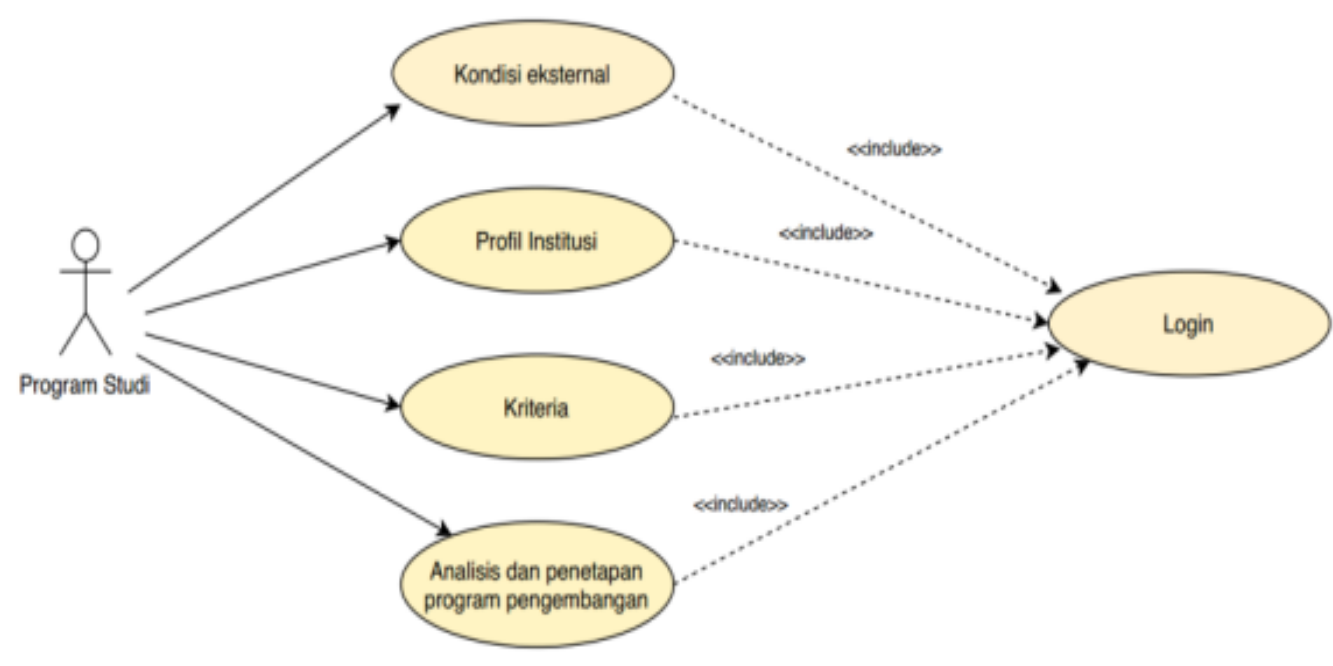

Gambar 3 Use case diagram program studi

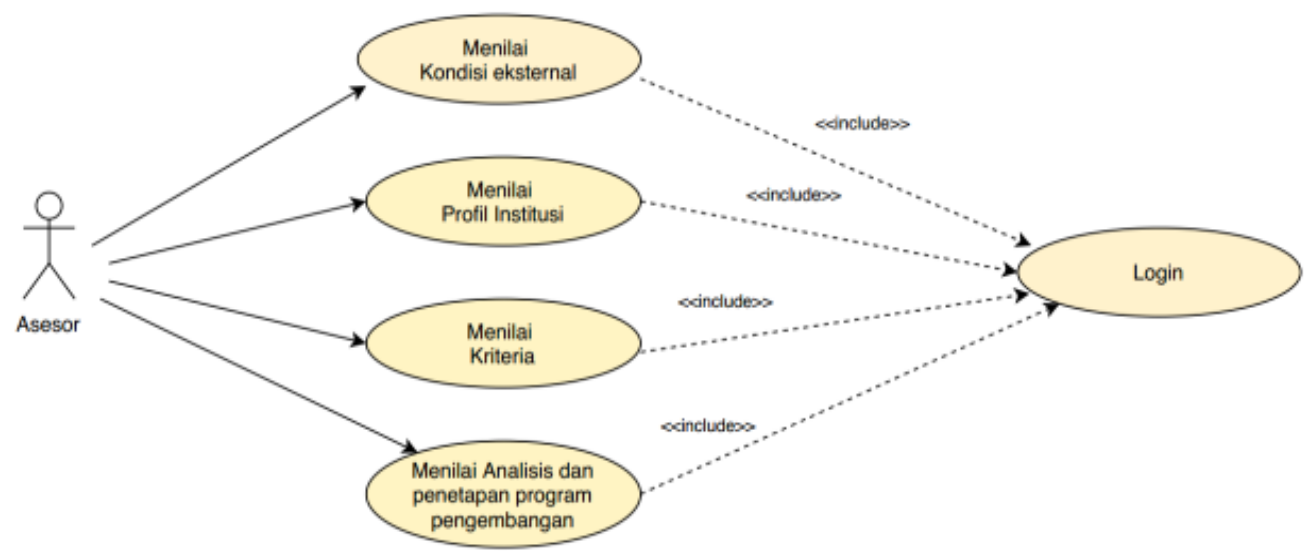

Gambar 4 Use case diagram asesor

Use case program studi memasukani data kondisi eksternal, profil institusi, kriteria dan analisis dan penetapan program pengembangan. Data yang diisikan oleh program studi akan di nilai oleh asesor. Use case Asesor menilai data kondisi eksternal, profil institusi, kriteria dan analisis dan penetapan program pengembangan. Nilai yang diisi oleh asesor akan dijadikan nilai akreditasi.

\section{Perancangan Fuzzy}

Pemanfaatan logika fuzzy dalam menentukan output pada status akreditasi harus melalui penentuan input yang sesuai untuk hasil yang diinginkan. Ada beberapa tahap yang akan digunakan untuk mendapatkan output yang diharapkan. Tahapan yang dimaksud adalah tahapan pembentukan model fuzzy.

\section{Fuzzifikasi}

Fuzzifikasi adalah suatu cara untuk mengubah peubah input menjadi fuzzy input. Peubah yang telah didefinisikan akan dibagi menjadi beberapa himpunan fuzzy dan kemudian akan dicari nilai dari masing-masing kuartilnya. Setelah itu akan dicari fungsi keanggotaannya dari tiap peubah input. Fungsi keanggotaan yang digunakan dalam karya ilmiah ini adalah fungsi keanggotan trapesium yang akan digunakan untuk memodelkan peubah fuzzy

1. Fuzzifikasi kondisi eksternal. Pada variabel kondisi eksternal didefinisikan tiga himpunan fuzzy, yaitu: kurang, cukup, baik. Untuk mempresentasikan variable kondisi

JAS-PT

JURNAL ANALISIS SISTEM PENDIDIKAN TINGGI ISSN $2580-5339$ eISSN $2620-5718$

Volume 4

Nomor 1

JULI 2020

Hal $67-76$

FORUM DOSEN INDONESIA 
eksternal digunakan bentuk kurva bahu kiri untuk himpunan fuzzy kurang, bentuk kurva trapesium untuk himpunan cukup dan bentuk bahu kanan untuk himpunan fuzzy baik.

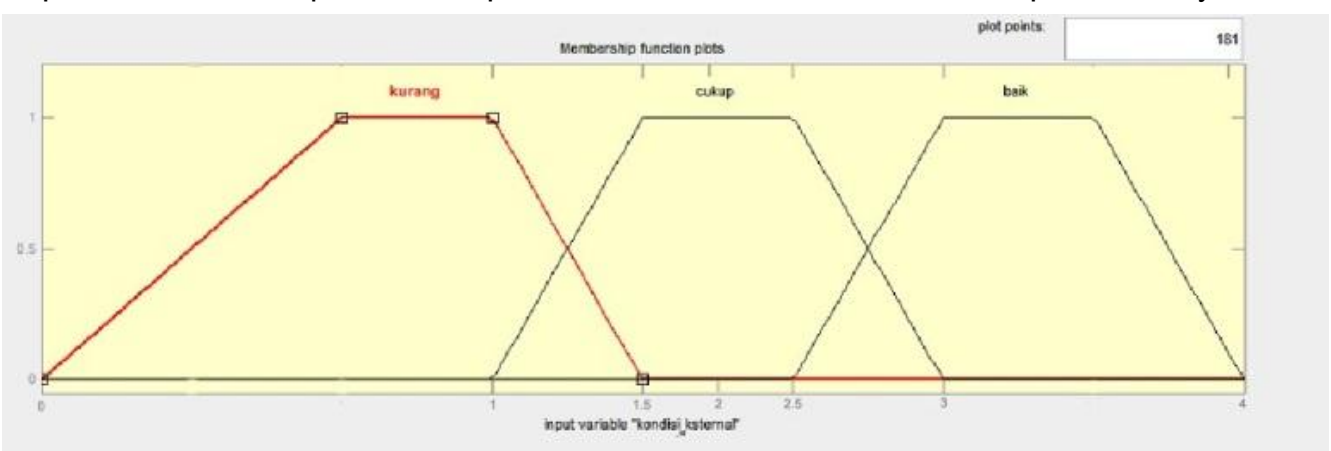

Gambar 5 Fuzzifikasi kondisi eksternal

2. Fuzzifikasi profil unit pengelola. Pada variabel profil unit pengelola didefinisikan tiga himpunan fuzzy, yaitu: kurang, cukup, baik. Untuk mempresentasikan variable kondisi eksternal digunakan bentuk kurva bahu kiri untuk himpunan fuzzy kurang, bentuk kurva trapesium untuk himpunan cukup dan bentuk bahu kanan untuk himpunan fuzzy baik.

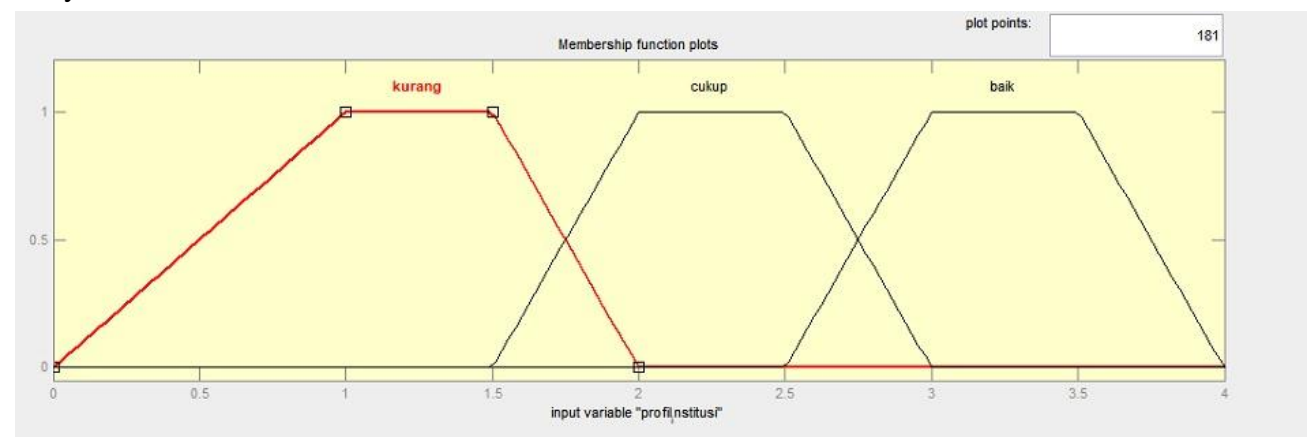

Gambar 6 Fuzzifikasi profil unit pengelola

3. Fuzzifikasi kriteria. Pada variabel kriteria didefinisikan tiga himpunan fuzzy, yaitu: kurang, cukup, baik. Untuk mempresentasikan variable kriteria digunakan bentuk kurva bahu kiri untuk himpunan fuzzy kurang bentuk kurva trapesium untuk himpunan cukup dan bentuk bahu kanan untuk himpunan fuzzy baik.

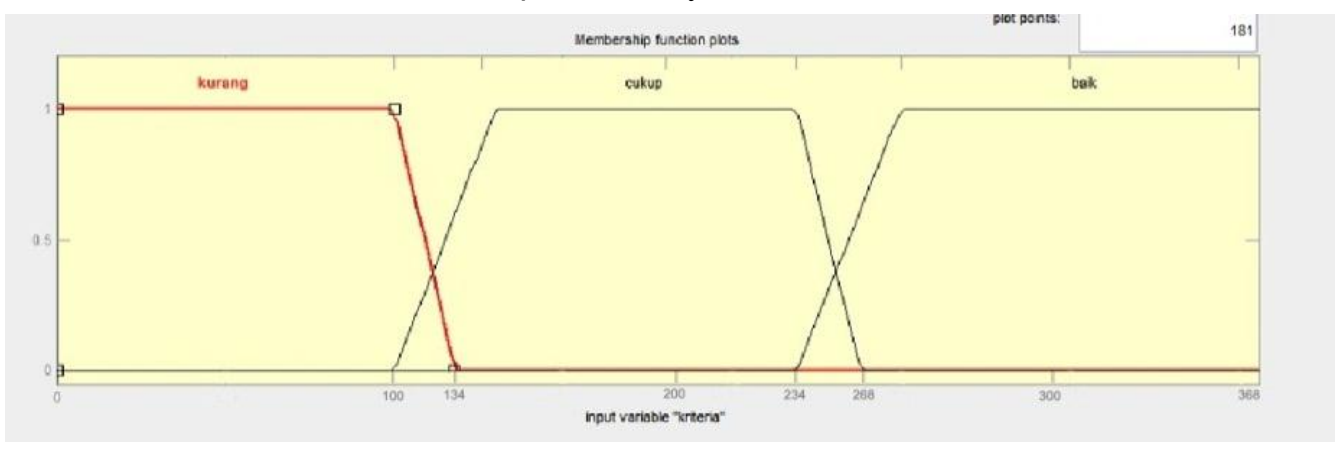

JAS-PT

JURNAL ANALISIS SISTEM PENDIDIKAN TINGGI

ISSN $2580-5339$

eISSN $2620-5718$

Volume 4

Nomor 1

JULI 2020

Hal 67 - 76

FORUM DOSEN INDONESIA

4. Fuzzifikasi analisis dan penetapan program pengembangan. Pada variabel analisis dan penetapan program pengembangan didefinisikan tiga himpunan fuzzy, yaitu: kurang, cukup, baik. Untuk mempresentasikan variable analisis dan penetapan program pengembangan digunakan bentuk kurva bahu kiri untuk himpunan fuzzy 
kurang [0-10], bentuk kurva trapesium untuk himpunan cukup dan bentuk bahu kanan untuk himpunan fuzzy baik.

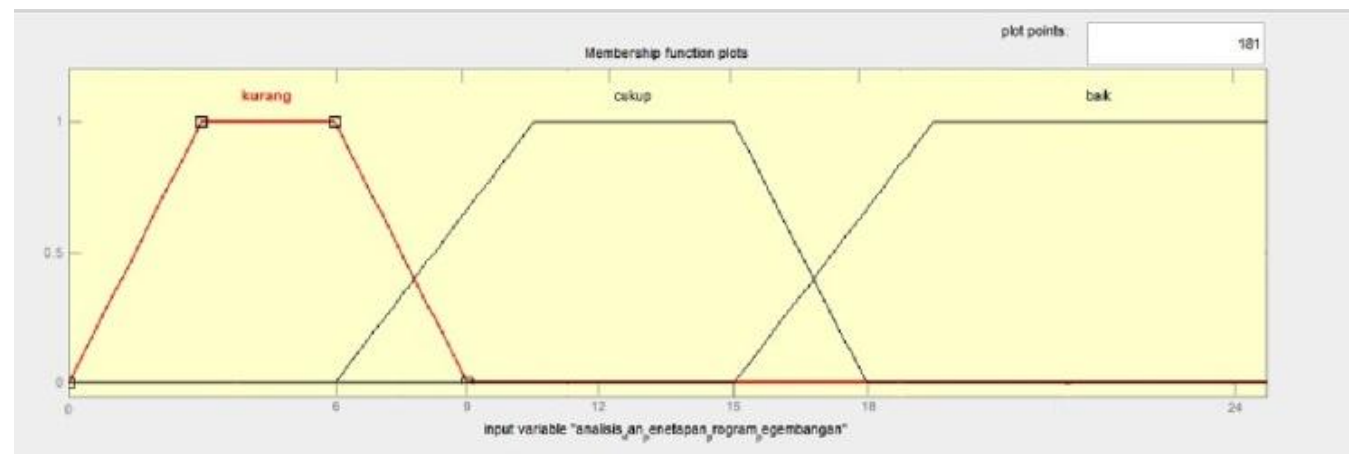

Gambar 8 Fuzzifikasi analisis dan penetapan program pengembangan

5. Fuzzifikasi status akreditasi. Pada variabel status akreditasi didefinisikan empat himpunan fuzzy, yaitu: tidak terakreditasi, terakreditasi baik, terakreditasi baik sekali dan terakreditasi unggul. Untuk mempresentasikan variable status akreditasi digunakan bentuk kurva bahu kiri untuk himpunan fuzzy tidak terakreditasi, bentuk kurva trapesium untuk himpunan terakreditasi baik, terakreditasi baik sekali, dan bentuk bahu kanan untuk himpunan fuzzy terakreditasi unggul.

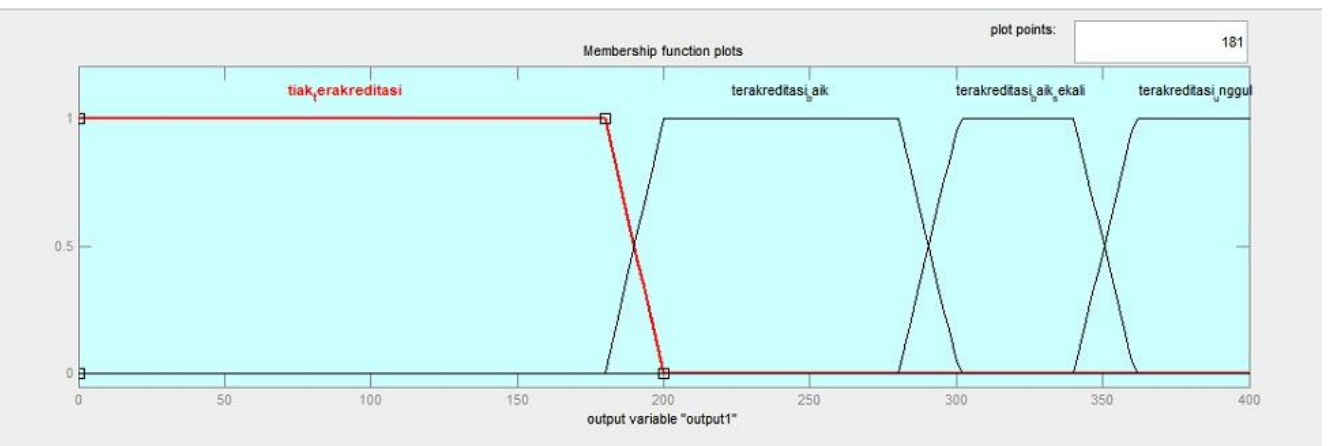

Gambar 9 Fuzzifikasi status akreditasi

Rules yang digunakan

Pada proses inferensi, ditentukan beberapa aturan yang akan digunakan untuk menarik kesimpulan. Berikut ini beberapa aturan yang ditentukan pada penelitian kali ini :

Tabel 1 Rule penilaian akreditasi

\begin{tabular}{cccccc}
\hline Aturan & $\begin{array}{c}\text { Kondisi } \\
\text { Eksternal }\end{array}$ & $\begin{array}{c}\text { Profil } \\
\text { Insitusi }\end{array}$ & Kriteria & $\begin{array}{c}\text { Analisis } \\
\text { PPP }\end{array}$ & Status Akreditasi \\
\hline R1 & Kurang & Kurang & Kurang & Baik & Tidak Terakreditasi \\
R2 & Kurang & Kurang & Kurang & Cukup & Tidak Terakreditasi \\
R3 & Kurang & Kurang & Kurang & Kurang & Tidak Terakreditasi \\
R4 & Cukup & Kurang & Kurang & Kurang & Tidak Terakreditasi \\
R5 & Cukup & Cukup & Cukup & Kurang & Terakreditasi Baik \\
R6 & Cukup & Cukup & Cukup & Cukup & Terakreditasi Baik \\
R7 & Baik & Cukup & Baik & Baik & Terakreditasi Baik Sekali \\
R8 & Baik & Baik & Baik & Cukup & Terakreditasi Baik Sekali \\
R9 & Baik & Baik & Baik & Baik & Terakreditasi Unggul \\
$\ldots$ & $\ldots$ & $\ldots$ & $\ldots$ & $\ldots$ & $\ldots$ \\
R81 & Baik & Cukup & Cukup & Cukup & Terakreditasi Baik \\
\hline
\end{tabular}

\section{Tahapan Penentuan Penilaian Akreditasi}

Berikut tahapan input sampai dengan penilaian serta sampai dengan keluar status akreditasi. Tahapan tahapan yang dilakukan sebagai berikut:

JAS-PT

JURNAL ANALSIS SISTEM PENDIDIKAN TINGG ISSN $2580-5339$ eISSN $2620-5718$

Volume 4

Nomor 1

JULI 2020

Hal $67-76$

FORUM DOSEN INDONESIA 
1. Input Data LKPS dan LED dilakukan oleh Program studi.

2. Input Penilaian setelah data LKPS dan LED diisi. Penilaian dilakukan oleh asesor.

Tabel 2 Tahapan input penilaian pada setiap indikator

\begin{tabular}{|c|c|c|c|c|}
\hline \multirow{2}{*}{ Program Studi } & \multicolumn{4}{|c|}{ Input Penilaian } \\
\cline { 2 - 5 } & $\begin{array}{c}\text { Kondisi } \\
\text { Eksternal }\end{array}$ & $\begin{array}{c}\text { Profil } \\
\text { Institusi }\end{array}$ & Kriteria & $\begin{array}{c}\text { Analisis dan } \\
\text { Penetapan } \\
\text { Program } \\
\text { Pengembangan }\end{array}$ \\
\hline Sistem Informasi & 2 & 2 & 221 & 15 \\
\hline Kategori & Cukup & Cukup & Cukup & Cukup \\
\hline
\end{tabular}

Tabel 2 menunjukan tahapan input untuk menentukan penilaian dari masing masing indikator. Pada indikator penilaian kondisi eksternal terdapat inputan 2 dengan kategori cukup, berikutnya profil institusi terdapat inputan 2 dengan kategori cukup, kemudian kriteria terdapat inputan 221 dengan kategori cukup dan terakhir analisis dan Penetapan Program Pengembangan dengan inputan 15 dengan kategori cukup. Setelah pengisian penilaian berikut dibawah ini Output dari penilaian akreditasi.

Tabel 3 Tahapan hasil output status akreditasi

\begin{tabular}{|c|c|}
\hline & Output \\
\hline Program Studi & Status Akreditasi \\
\hline Sistem Informasi & Terakreditasi Baik \\
\hline
\end{tabular}

Tabel 3 menunjukan tahapan output untuk menentukan status akreditasi untuk kategori inputan pada tabel 2 masuk pada kategori terakreditasi baik.

Implementasi Sistem

Aplikasi sistem akreditasi yang pertama dilakukan adalah membuka web browse. Pada aplikasi sistem akreditasi, setiap pengguna yang akan melakukan login masuk pada aplikasi harus memiliki identitas akun, (user id) dan kata sandi (password). Berikut tampilan sistem penilaan dan defuzzyfikasi dari hasil inputan.

JAS-PT

JURNALANALISIS SISTEM PENDIDIKAN TINGGI ISSN $2580-5339$ eISSN $2620-5718$

Volume 4

Nomor 1

JULI 2020

Hal 67 - 76

FORUM DOSEN INDONESIA

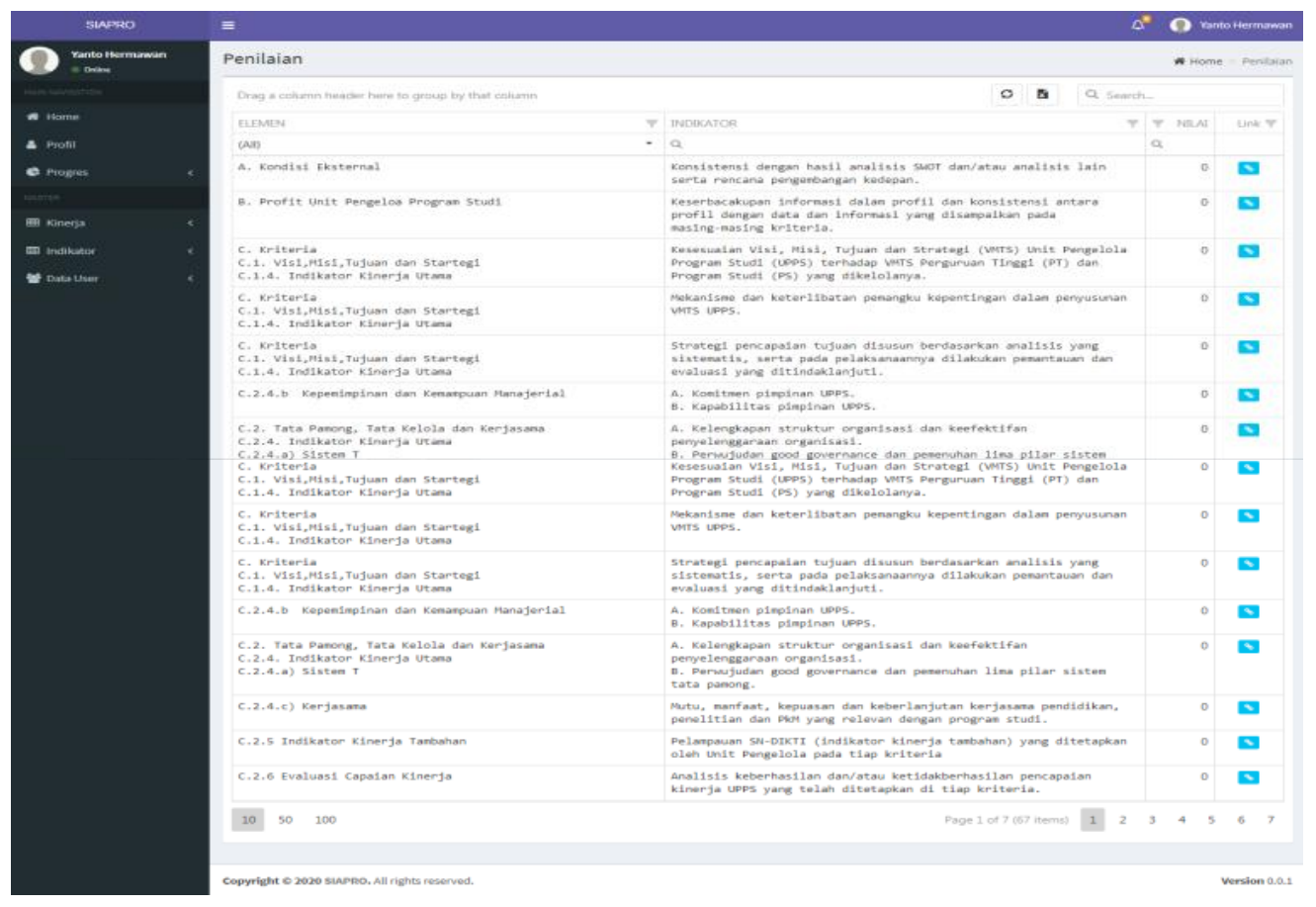

Gambar 10 Tampilan menu penilaian 
Hasil penerapan system fuzzy dengan aplikasi SIAPRO, setelah data nilai telah diinput nilai yang diperoleh program studi sistem informasi S1 nilai sebesar 297 dengan status akreditasi baik, dengan demikian program studi sistem informasi S1 direkomendasikan untuk dapat diajukan ke BAN-PT.

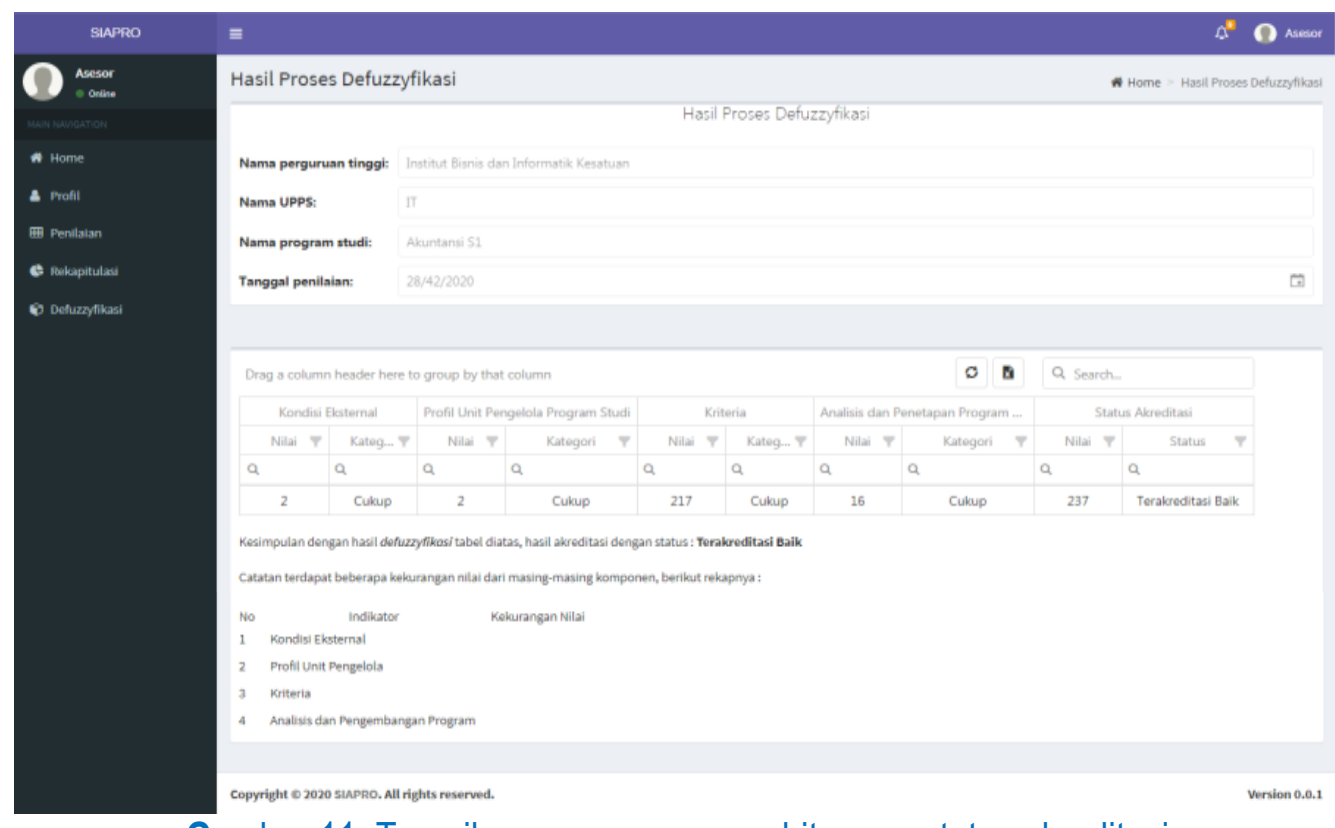

Gambar 11 Tampilan menu proses perhitungan status akreditasi

\section{Pengujian Sistem}

Tabel 3 Pengujian sistem akreditasi

\begin{tabular}{|c|c|c|c|}
\hline $\begin{array}{c}\text { Nama } \\
\text { Pengujian }\end{array}$ & Skenario Pengujian & $\begin{array}{l}\text { Hasil yang } \\
\text { diharapkan }\end{array}$ & $\begin{array}{c}\text { Hasil } \\
\text { pengujian }\end{array}$ \\
\hline $\begin{array}{l}\text { Lihat menu } \\
\text { kriteria }\end{array}$ & Klik menu kriteria & $\begin{array}{l}\text { Tampil halaman } \\
\text { kriteria }\end{array}$ & Valid \\
\hline $\begin{array}{l}\text { Lihat menu } \\
\text { indikator }\end{array}$ & Klik menu indikator & $\begin{array}{l}\text { Tampil halaman } \\
\text { indikator }\end{array}$ & Valid \\
\hline Lihat data user & Input data & Tampil halaman user & Valid \\
\hline Input data LKPS & Input data & $\begin{array}{l}\text { Tampil halaman } \\
\text { LKPS }\end{array}$ & Valid \\
\hline Input data LED & Input data & Tampil halaman LED & Valid \\
\hline $\begin{array}{l}\text { Input penilaian } \\
\text { LKPS dan LED }\end{array}$ & Input data nilai & $\begin{array}{l}\text { Tampil halaman } \\
\text { penilaian }\end{array}$ & Valid \\
\hline $\begin{array}{l}\text { Lihat } \\
\text { rekapitulasi }\end{array}$ & $\begin{array}{l}\text { Klik menu } \\
\text { rekapitulasi }\end{array}$ & $\begin{array}{l}\text { Tampil halaman } \\
\text { rekapitulasi }\end{array}$ & Valid \\
\hline
\end{tabular}

\section{PENUTUP}

Penelitian ini telah berhasil mengembangkan sistem informasi akreditasi dengan 9 kriteria. Metode yang digunakan yaitu menggunakan fuzzy inference system. Dengan inputan data LKPS dan LED kemudian dilakukan penilaian kriteria yang ditentukan sebanyak 4(empat) yaitu kondisi eksternal, profil insitusi, kriteria dan analisis dan penetapan program pengembangan. Kemudian sistem berhasil membuat menu pengisian indikator, menu pengisian data LKPS, menu pengisian data LED, menu penilaian LKPS dan LED dan menu rekapitulasi beserta kesimpulannya. Dari hasil yang didapatkan untuk program studi S1 Sistem Informasi didapatkan hasil dengan status akreditasi adalah terakreditasi baik. Status akreditasi tersebut didapatkan dari hasil

JAS-PT

JURNAL ANAUSIS SISTEM PENDIDKAN TING ISSN $2580-5339$ elSSN $2620-5718$

Volume 4

Nomor 1

JULI 2020

Hal 67 - 76

FORUM DOSEN INDONESIA 
penilaian yang dilakukan oleh asesor dengan melihat beberapa kriteria yang terdiri dari kondisi eksternal, profil insitusi, kriteria dan analisis dan penetapan program pengembangan. Berdasarkan hasil pengujian menggunakan blackbox testing menunjukkan bahwa fitur dalam aplikasi SIAPRO penggunaan menu-menu pada sistem mampu berjalan dengan baik sesuai dengan kebutuhan.

\section{DAFTAR PUSTAKA}

[BAN-PT] Badan Akreditasi Nasional Perguruan Tinggi. 2019. Peraturan Badan Akreditasi Nasional Perguruan Tinggi Nomor 2 Tahun 2019 tentang Panduan Penyusunan Laporan Evaluasi dan Panduan Penyusunan Laporan Kinerja Program Studi Dalam Instrumen Akreditasi Program Studi. Jakarta (ID): BANPT.

[BAN-PT] Badan Akreditasi Nasional Perguruan Tinggi. 2019. Peraturan Badan Akreditasi Nasional Perguruan Tinggi Nomor 5 Tahun 2019 tentang Instrumen Akreditasi Program Studi Pedoman Penilaian. Jakarta (ID): BAN-PT

Hamidah I. 2018. Pengembangan Sistem Informasi Akreditasi Berbasis Web Modul Keuangan, Sarana, Prasarana Dan Sistem Pembelajaran Pada Program Sarjana [skripsi]. Bogor(ID): Institut Pertanian Bogor.

[KEMENRISTEKDIKTI] Kementerian Riset, Teknologi, dan Pendidikan Tinggi. 2016. Peraturan Menteri Pendidikan Dan Kebudayaan Republik Indonesia Nomor 59 Tahun 2012 Tentang Badan Akreditasi Nasional Pasal 1 No 4. Jakarta (ID): Kementerian Ristekdikti.

[KEMENRISTEKDIKTI] Kementerian Riset, Teknologi, dan Pendidikan Tinggi. 2016. Peraturan Menteri Pendidikan dan Kebudayaan Republik Indonesia Nomor 59 Tahun 2012 Tentang Badan Akreditasi Nasional Pasal 1 No 8. Jakarta (ID): Kementerian Ristekdikti.

Khudzaeva E. 2014. Rancang Bangun Sistem Arsip Akreditasi (Studi Kasus : Fakultas Sains dan Teknologi UIN Syarif Hidayatullah Jakarta). Jurnal Sistem Informasi 7(2): 1-9.

Kusumadewi S., Purnomo H. 2003. Aplikasi Logika Fuzzy untuk pendukung keputusan Jakarta (ID) Graha IImu.

Maulana RR. 2014. Pengembangan Modul Keuangan pada Sistem Informasi Akreditasi Program Studi (SIAPS) Menggunakan Agile Unified Process. [skripsi]. Bogor(ID): Institut Pertanian Bogor.

Mustafadiah H. 2013. Konsep Dasar Logika Fuzzy dan Contoh Aplikasinya. Yogyakarta (ID) Pustaka Pelajar \& UMP Press.

Nasution. H. 2012. Implementasi Logika Fuzzy pada Sistem Kecerdasan Buatan. Jurnal Implementasi Logika Fuzzy Pada Sistem Kecerdasan Buatan Universitas Tanjungpura.

O'Brien JA, Marakas GM. 2010. Introduction to Information Systems. Ed ke-15. New York (US): McGraw-Hill.

JAS-PT

JURNAL ANALISIS SISTEM PENDIDIKAN TING ISSN $2580-5339$ eISSN $2620-5718$ Volume 4

Nomor 1

JULI 2020

Hal $67-76$

FORUM DOSEN INDONESIA 